\title{
MEMÓRIA, CIDADANIA E DIREITOS DE COMUNIDADES REMANESCENTES \\ (EM TORNO DE UM DOCUMENTO DA HISTÓRIA \\ DOS QUILOMBOLAS DA MARAMBAIA)*
}

\author{
Daniela Yabeta \\ Flávio Gomes ${ }^{* * * *}$
}

$\mathrm{N}$ as últimas duas décadas, dois temas fundamentais da sociedade brasileira (e do pensamento social do século XX) se cruzaram em termos de lutas sociais, políticas públicas e ações judiciais: a questão agrária e as políticas de promoção da igualdade racial. Lutas históricas pela reforma agrária ganharam, desde o final da década de 80 , mais e outros capítulos com a mobilização das comunidades remanescentes de quilombos. Segundo a Constituição de 1988, caberia ao Estado brasileiro reconhecer, certificar, demarcar e titular as terras das comunidades remanescentes de quilombos espalhadas de norte a sul do País. Embates jurídicos e acadêmicos, mobilizações dos movimentos sociais e reações de setores ruralistas foram constantes. Segundo dados da Fundação Cultural Palmares, do INCRA e de outros órgãos e instituições, estima-se que existam hoje no Brasil cerca de 5.000 comunidades, sendo que aproximadamente 193 tiveram a sua titulação finalizada. Após oito anos de tramitação, em abril de 2012, o Supremo

\footnotetext{
Esta pesquisa está sendo financiada por diferentes fontes: CAPES, CNPq e FAPERJ (Fundação de Apoio a Pesquisa do Estado do Rio de Janeiro).

** Doutoranda em História da Universidade Federal Fluminense. danielayabeta@gmail.com

**** Professor da Universidade Federal do Rio de Janeiro. escravo@ prolink.com.br
} 
Tribunal Federal começou a julgar a ação direta de inconstitucionalidade (Adin) contra o Decreto presidencial 4.887/2003, regulamentando a titulação das terras dos quilombolas. Os principais embates em torno desta Adin (ação movida pelo partido Democratas, o DEM) giram em torno da contestação dessa regulamentação. Há alegações sobre o suposto caráter inconstitucional e a superposição legislativa da regulamentação. Mais do que uma disputa política com desdobramentos parlamentares, estão em jogo perspectivas de identidade, territorialização e autorreconhecimento das comunidades quilombolas. Quem define que uma comunidade rural negra é remanescente de quilombo? Tão somente sua história, cultura, memória social e identidade autodeclarada de sua população? Ou a burocracia do Estado, com ações de comprovação documental, perícia e laudos antropológicos, históricos ou arqueológicos?

Neste artigo, abordamos uma face deste debate para a comunidade remanescente de quilombos da Ilha da Marambaia no Rio de Janeiro. Será o fio condutor para apresentar alguns documentos inéditos sobre os quilombos históricos locais do século XIX. Mais do que uma perspectiva positivista, ou de qualquer "verdade histórica", sugerimos vários caminhos que possam articular diversas áreas do conhecimento sobre experiências da escravidão, pós-Abolição e a realidade atual das formas camponesas no Brasil, especialmente aquelas das comunidades remanescentes de quilombos.

\section{Sobre a Marambaia}

A Ilha da Marambaia está localizada no município de Mangaratiba, sul do estado do Rio de Janeiro. Em abril de 1847, ela foi vendida por José Guedes Pinto e seu irmão ao comendador Joaquim José de Souza Breves. ${ }^{1}$ Devido às determinações da Lei de Terras de 1850 , Breves registraria a ilha como sua propriedade somente em 1856, no livro de terras da Paróquia de Santana de Itacurussá. ${ }^{2}$

1 A notícia da compra da propriedade foi posteriormente publicada pelo próprio comendador na imprensa da Corte. Ver a seção Correspondência do Jornal do Commercio, 6 de março de 1851.

2 Arquivo Público do Estado do Rio de Janeiro (doravante APERJ), Livro de Registro de Terras número 50. Freguesia de Sant`Anna de Itacurussá, 27 de fevereiro de 1856, folha 8v. 
Nesta época, o poder econômico e político de Joaquim Breves e sua família, em várias regiões do sul fluminense, alcançando parte do Vale do Paraíba, já era grande. ${ }^{3}$ Um dos maiores fazendeiros de café do sudeste escravista ficou conhecido também pelo seu envolvimento com o tráfico atlântico de africanos mesmo após a sua proibição. ${ }^{4}$ Assim como outros fazendeiros, negociantes e autoridades coniventes, o comendador ignorou completamente a decisão do governo imperial de 1831, que tornava ilegal o tráfico de africanos para o Brasil. Pelo contrário, sua participação no comércio atlântico aumentou. E a Ilha da Marambaia foi importantíssima neste processo. Breves aproveitou a sua localização estratégica para área de desembarque ilegal de africanos que abasteceriam as suas fazendas, e certamente outras, alcançando várias partes das importantes áreas cafeeiras. Há indicações de que as conexões entre o tráfico de africanos e os desembarques ilegais na ilha eram antigas. Existem denúncias de pelo menos quatro desembarques na década de 30. Em 1837, as acusações recaíram sobre o bergantim Leão, com 572 africanos desembarcados. Dois anos depois, em 1839, os alvos foram os brigues D. João de Castro, que teria desembarcado 450 africanos antes da sua apreensão, e o Resolução, com 421 desembarcados. Depois, as denúncias contra o brigue Fluminense revelaram que o mesmo pertencia a Antônio Dias Pavão e a João José dos Santos Breves, um irmão do comendador Breves. ${ }^{5}$

Mesmo com a promulgação da legislação antitráfico em setembro de 1850, a Lei Eusébio de Queiroz, as movimentações na Marambaia de desembarques de africanos continuaram. A única mudança ficou por conta de uma nova legislação que alterava a tramitação dos processos judiciais referentes a esse comércio ilegal. Através de seu artigo $4^{\circ}$ passaria a ser considerado "crime de pirataria", com o apresamento das embarcações suspeitas, a condenação dos traficantes e

3 Maria Sylvia de Carvalho Franco, Homens Livres na Ordem Escravocrata, São Paulo: Káiros, 1983.

4 Thiago Campos Pessoa Lourenço, "O Império dos Souza Breves nos oitocentos: política e escravidão nas trajetórias dos comendadores José e Joaquim de Souza Breves (Dissertação de Mestrado, Universidade Federal Fluminense, 2010).

5 Arquivo do Itamaraty (doravante AI), Anais da Câmara. Coleção Ministério da Justiça, Tomo IV. Rio de Janeiro, 1880./ Lourenço, "O Império dos Souza Breves nos oitocentos", p. 134. 
a liberação dos africanos apreendidos. E o artigo $8^{\circ}$ determinava que todos os acusados fossem julgados por um tribunal especial, no caso a Auditoria Geral da Marinha. Ainda assim a Marambaia continuaria sob foco, pois entre 1850 e 1851 foi palco de mais denúncias. Primeiro, no final de 1850, com a apreensão do iate Jovem Maria, transportando 291 africanos. No ano seguinte, pelo menos 199 africanos, considerados boçais e recém-chegados, acabariam apreendidos na ilha numa diligência sob o comando do chefe de polícia interino da Corte Bernado Azambuja. Logo depois, mais um navio, o patacho Actividade, foi apreendido, tendo desembarcado 455 africanos. ${ }^{6}$

Denúncias, em parte fruto do jogo político da época envolvendo imprensa, partidos políticos e autoridades imperiais, pipocavam. Em 1853, o comendador Breves foi indiciado pelo crime de importação de africanos. Levado a júri, em Angra dos Reis, acabaria absolvido da acusação de ter participação no desembarque de aproximadamente 500 africanos trazidos pelo barco americano Camargo até o porto do Bracuí (Angra dos Reis), propriedade de seu irmão mais velho José Joaquim de Souza Breves. ${ }^{7}$

Na Marambaia, ao que se sabe, foi estabelecida uma fazenda com escravos, além de barracões e instalações improvisadas para o comércio ilegal de africanos. Mas não há muita informação - comparada com outras grandes propriedades do comendador Breves que alcançavam Piraí, Rio Claro e São João Marcos - sobre a quantidade de escravos que permaneceram na ilha na segunda metade do século XIX. Segundo a memória dos atuais e mais antigos moradores da Marambaia, que configuram uma comunidade negra rural, o comendador Breves antes de morrer (em setembro de 1889) teria feito uma doação de "boca", posto não formalizada em testamento ou cartório, das terras nas margens das praias para as famílias de ex-escravos que permaneceram vivendo na

6 Sobre o tráfico ilegal de africanos na Ilha da Marambaia, ver: Daniela Yabeta, "A capital do comendador: a Auditoria Geral da Marinha no julgamento sobre a liberdade dos africanos apreendidos na Ilha da Marambaia (1851)" (Dissertação de Mestrado, UNIRIO, 2009); Lourenço, "O Império dos Souza Breves nos oitocentos".

7 Martha Abreu, "O caso do Bracuí", in Hebe Mattos e Schnoor Eduardo (orgs.), Resgate: uma janela para o oitocentos (Rio de Janeiro: Topbooks, 1995). 
ilha. As terras continuariam propriedades dos herdeiros, e segundo Fânia Fridman houve incentivo para a utilização delas através da meação. ${ }^{8}$ Mas, em 1891, a viúva Maria Isabel de Moraes Breves não manteve o compromisso do marido e acabou vendendo a Ilha da Marambaia à Companhia Promotora de Indústria e Melhoramentos. ${ }^{9}$ A história de posse que se seguiu não foi menos complexa do que aquela das décadas da escravidão, ocupação, desembarques de africanos e mesmo de grupos de quilombolas, como mostraremos. Isto porque, em 1896, a referida companhia, em liquidação forçada, transferiu a propriedade para $\mathrm{o}$ Banco da República do Brasil. ${ }^{10}$ Diante de aguda crise financeira, a instituição bancária faria um acordo com a União Federal repassando bens, capitais e imóveis para abater as dívidas que se acumulavam. Entre as propriedades figurava a Ilha da Marambaia adquirida em 1905. ${ }^{11}$

No século XX, sua vocação para empreendimentos marítimos se manteve. Em termos de ocupação, ficaram morando na ilha as famílias de ex-escravos, certamente libertos, oriundos também de outras fazendas e áreas de influência escravista da família Breves, além de camponeses, pescadores e sitiantes itinerantes que chegaram entre os derradeiros anos do século XIX e as primeiras décadas do século seguinte. Em 1908, a Marinha do Brasil instalou ali a Escola de Aprendiz de Marinheiros do Estado do Rio de Janeiro, que funcionou até 1910, sendo depois transferida para o município de Campos. ${ }^{12}$ Em 1939, durante o governo de Getú-

8 Fânia Fridman, Donos do Rio em nome do rei, Rio de Janeiro: Jorge Zahar, 1999, p.180.

9 Processo no 2002.5111000118-2 - Ação Civil Pública - Marinha do Brasil - Comando-Geral do Corpo de Fuzileiros Navais - Subsídios preliminares à contestação do RTID - Venda da ilha à Companhia Promotora de Indústria e Melhoramentos - Inventário registrado no cartório do $2^{\circ}$ Ofício de Registro de Imóveis do Município de Rio Claro, p. 1.860.

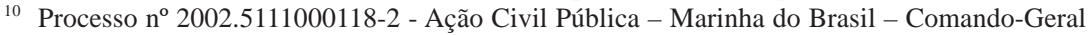
do Corpo de Fuzileiros Navais - Transferência da ilha para o Banco da República do Brasil, em face da liquidação forçada da Companhia Promotora de Indústria e Melhoramentos Escritura lavrada no $3^{\circ}$ Ofício de Notas, livro 557, fls. 80V/81V, p. 1.860.

11 Processo no 2002.5111000118-2 - Ação Civil Pública - Marinha do Brasil - Comando-Geral do Corpo de Fuzileiros Navais - Aquisição da ilha pela União - Lei 1316 de dezembro de 1904. Escritura lavrada no Cartório do $9^{\circ}$ Ofício de Notas, livro 2, fl.97, p. 1.860.

12 Processo no 2002.5111000118-2 - Ação Civil Pública - Marinha do Brasil - Comando-Geral do Corpo de Fuzileiros Navais - 1906 - Recebimento da administração da ilha pela Marinha: Aviso $n^{\circ} 48$ do Ministério da Marinha/ 1908 - Instalação da Escola de Aprendizes de Marinheiros na ilha: Aviso Ministerial no 2671./ 1910 - Transferência da Escola de Aprendizes de Marinheiros para a cidade de Campos dos Goytacazes. Aviso Ministerial n²546, p. 1.860. 
lio Vargas, foi instalada a Escola de Pesca Darcy Vargas, administrada pela Fundação Abrigo Cristo Redentor, que funcionou até 1970. Esta escola não foi necessariamente construída para atender a população da ilha, ainda que alguns moradores a tenham frequentado. Seu principal objetivo era dar formação profissional para os filhos de pescadores tradicionais de várias regiões do litoral brasileiro. ${ }^{13}$

Com o fechamento da Escola de Pesca, a ilha voltou aos cuidados da Marinha, pelo Decreto 68.224 de 12 de fevereiro de $1971 .{ }^{14}$ Dez anos mais tarde seria instalado o Centro de Adestramento da Ilha da Marambaia (CADIM), com a missão primordial de "contribuir para o aprestamento de Forças Navais e de Fuzileiros Navais", além de garantir a "preservação do patrimônio da Marinha na Ilha da Marambaia". ${ }^{15}$ Em 17 de maio 1972 foi promulgado o Aviso no 0485 assinado pelo Ministro da Marinha. Com vários artigos, trata-se de um documento revelador expectativas e das políticas implementadas na Ilha da Marambaia no tocante a sua ocupação e as relações com a população local. No seu artigo $1^{\circ}$ instituiu a "Prefeitura Naval da Ilha da Marambaia", que, com o caráter temporário, estava encarregada de fazer a transição da administração da Escola de Pesca para o Comando Militar. De acordo com o artigo $4^{\circ}$, tal prefeitura naval também tinha a função de "normalizar a vida local através de ações administrativas" que não deveriam ser conduzidas pelo comandante do Corpo de Fuzileiros Navais, "a fim de não constituir sobrecarga a essa autoridade". Seu funcionamento estava previsto até 31 de dezembro de $1972 .{ }^{16}$ Vejamos em detalhe o texto do artigo $1^{\circ}$ do referido Aviso que tratava da necessidade de se definir a população que deveria permanecer na ilha em face à necessidade de utilização da área. O item "j" determinava que fosse providenciada a

13 Vladimir, "A antiga escola da Marambaia: história e memória de uma experiência do ensino industrial da pesca (1939-1970)" (Dissertação de Mestrado, Pontifícia Universidade Católica, 2010).

14 Decreto $n^{\circ} 6.8224$ de 12 de fevereiro de 1971 - Autoriza a reincorporação ao patrimônio da União dos bens móveis e imóveis da Escola Técnica Darcy Vargas, da Fundação Abrigo Cristo Redentor.

15 CADIM - Centro de Adestramento da Ilha da Marambaia. Forças Terrestres. Rio de Janeiro. Disponível em: <www.forte.jor.br> Acesso em: 08 maio, 2012.

16 Prefeitura Naval da Ilha da Marambaia (doravante PNIM), Aviso no 0485 de 17 de maio de 1972. 
dispensa de 30 dos 42 funcionários civis que viviam na ilha, ou seja, os que eram empregados da Escola de Pesca. Apenas 12 funcionários (com suas famílias) foram absorvidos pela Marinha e "empregados em atividades locais, visando o aproveitamento de suas experiências e capacidades profissionais individuais". Já o item "l" determinava que fossem redistribuídas as casas entre civis remanescentes, neste caso os 12 funcionários restantes, "sendo destruídos os casebres e edificações" que demonstrassem ser "irrecuperáveis, de condições higiênicas precárias, inadequadas aos seus fins ou de alto custo de reparação". O item "m" determinava que fosse demarcada a área geográfica de responsabilidade do Comando dos Fuzileiros Navais e o recenseamento dos civis que residiam no interior dessa área, a ser constituído "tão somente pelo pessoal que presta serviço". Por último, constava no item "m" que a Marinha estaria "desvinculada de toda e qualquer obrigação quanto ao pessoal que habita área não da Marinha". ${ }^{17}$

Embora não seja possível indicar com maiores evidências a densidade demográfica da população da Ilha da Marambaia, considerando as pioneiras famílias de ex-escravos e depois colônias de pescadores e sitiantes do início do século XX, há indícios - a memória da população da ilha é só parte deles - que apontam para uma paulatina política de exclusão e de expulsão coincidindo com a ocupação da Marinha. Não só através da demissão dos ex-funcionários da Escola de Pesca, mas também, como consta no item "g" do mesmo artigo, pela determinação de que "as atividades secundárias de caráter agropecuário fossem reduzidas a dimensões mínimas". E mais ainda, que fosse oferecida apenas uma escola primária sob responsabilidade da Secretaria de Educação do Estado do Rio de Janeiro, conforme consta no item "c". ${ }^{18}$

Nas memórias de Bertolino Dorothéa Rosa Filho e de outros moradores, na década de 70 (este novo formato de ocupação militar da Marinha começa em 1971) havia aproximadamente 600 famílias na ilha, número hoje reduzido para cerca de cem. ${ }^{19}$ As deliberadas restrições ao

\footnotetext{
17 Prefeitura Naval da Ilha da Marambaia (doravante PNIM), Aviso n 0485 de 17 de maio de 1972.

18 PNIM, Aviso n 0485 de 17 de maio de 1972.

19 Entrevista realizada em 14 de abril de 2012.
} 
trabalho, ao acesso a terra e as limitações educacionais produziram um processo parcial de auto-exclusão em dezenas de famílias de antigos moradores, parte das quais optando pela migração (embora muitas tivessem depois retornado) itinerante para outras áreas, abandonando temporariamente a ilha. ${ }^{20}$

Na década de 90, aumenta a pressão sobre os moradores da ilha da Marambaia com vários inquéritos militares e episódios diários de constrangimentos e intolerância. Segundo a memória local, era comum a convocação de moradores para prestar esclarecimentos junto ao comando militar na ilha a respeito de obras e de atividades nas áreas em que estavam morando, numa ocupação mais do que centenária e histórica. Houve até mesmo tentativas de expulsão e truculências. A população mais antiga manifestou logo suas expectativas de direitos adquiridos sobre aqueles territórios e reagiu à expulsão e à convivência com atitudes hostis e truculência sobre as suas formas sociais de vida e ocupação. ${ }^{21} \mathrm{O}$ conflito encontraria o caminho do judiciário com várias ações de reintegração de posse ajuizadas pela União Federal. Apenas entre 1996 e 1998 localizamos pelo menos 12 processos contra moradores da Marambaia, em geral acusando-os de "invasores do território". É interessante notar como as diversas ações judiciais foram distribuídas por diferentes varas federais, numa evidente tentativa de descaracterizar a expulsão de toda comunidade. ${ }^{22}$

20 Entrevista realizada em 14 de abril de 2012.

21 Processo no 96.0005706-0 - Ação de Reintegração de Posse ajuizada pela União Federal contra Paulo Vicente Machado - 16 abr, 1996. Relatório/ Reservado. Foram interrogados pelo Comando Militar na Ilha da Marambaia os seguintes moradores: Beatriz Maria Innocênio, Gisélia Campos dos Santos, Paulo Vicente Machado, Reginaldo Alves e Sebastião Santana. O único que demoliu a construção conforme determinação do Comando da Marinha foi Reginaldo Alves. Todos os outros moradores se recusaram a demolir. Os autos foram conclusos "de acordo com o $\S 1^{\circ}$ do art. 22 do Código de Processo Penal Militar-Decreto n 1002 de 21 de outubro de 1969 - pp. 24-6.

22 De acordo com o procurador Daniel Sarmento: “A estratégia utilizada foi a da fragmentação do litígio, apesar de sua irrecusável dimensão coletiva: ao invés de uma ação visando a retirada de todos os moradores da comunidade étnica, são ajuizadas demandas individuais contra alguns deles, já que é mais fácil enfrentar isoladamente cada família hipossuficiente do que entrar em confronto com toda aquela coletividade". Ver: Processo $\mathrm{n}^{\circ} 2002.5111000118-2$ Ação Civil Pública - Ministério Público Federal. 14 de fevereiro de 2002, p. 3. 


\section{Sobre as polêmicas}

Conflitos com desdobramentos judiciais coincidiram com um importante movimento social na Marambaia. A população local passaria a reivindicar os seus direitos territoriais, posse e demarcação, baseada também na afirmação de sua identidade de remanescente de quilombos, na região desde o século XIX. Teriam início outras batalhas: no campo jurídico, das políticas públicas e das instituições governamentais ou não, relacionadas aos direitos constitucionais sobre a posse de terras da Marambaia. Laudos, contra-laudos, embargos judiciais, reportagens, visitas formais de autoridades e parlamentares, mobilização de ministros (da Defesa e da Secretaria Especial da Promoção da Igualdade Racial - SEPPIR) e autoridades de órgãos estaduais e federais como Ministério Público, INCRA, ITERJ (Instituto de Terras do Estado do Rio de Janeiro), Procuradoria Federal e Fundação Cultural Palmares deram o tom. Intelectuais, ativistas, articulistas da grande imprensa, políticos, acadêmicos e autoridades se manifestaram e escreveram a respeito. Não faltaram argumentos, retóricas e narrativas sobre direitos étnicos, cidadania, manipulação da história e da memória.

Um episódio revelador, envolvendo dona Zenilda Soares Felicíssimo, merece aqui destaque, por nos ajudar a conectar os debates em questão, seus interessados, interlocutores, intermediários e desdobramentos. Em 16 de maio de 1996, a União Federal, através de seu representante judicial Flávio Collares Werneck, ajuizou uma ação de reintegração de posse contra esta moradora da casa $n^{\circ} 2$ na Praia da Armação. ${ }^{23} \mathrm{Na}$ ação, a União Federal argumentou que, durante inspeções realizadas pelo CADIM, foi verificado que dona Zenilda não residia mais naquele imóvel e, além disso, não possuía mais autorização militar para ocupar "esporadicamente" a casa. Por conta disso, foi instaurada uma "sindicância" em 26 de janeiro de 1995. Apesar da alegação de que dona Zenilda residia no subúrbio carioca do Irajá, constava na ação que ela foi interrogada dentro do comando militar da Marambaia, tendo a mesma informado que o imóvel pertencia a sua família, e

${ }^{23}$ Processo n ${ }^{\circ}$ 96.0007682-0 - Ação de Reintegração de Posse ajuizada pela União Federal contra Zenilda Soares Felicíssimo - 16 de maio 1996. 
com o falecimento de sua mãe, dona Iracema Feliciano Soares, em 18 de agosto de 1994, passou a ser a responsável pela casa. A conclusão da sindicância foi que dona Zenilda, de acordo com o art.71 do Decreto Lei 9760 de 5 de agosto de 1946 que dispõe sobre os bens imóveis da União, por ocupar imóvel da União sem autorização, poderia ser sumariamente despejada e sem indenização. Por conta disso, a União solicitava a "desocupação liminar" e o cálculo de perdas e danos na base de um salário mínimo por dia "a partir da data de citação até a restituição do imóvel", pagamento de indenização pelos "reparos que se fizessem necessários a restauração do imóvel", além do pagamento de "custas judiciais e honorários advocatícios com base de 20\%" com o objetivo de "desencorajar esse procedimento ilícito e lanoso ao país". ${ }^{24}$

Para fundamentar a ação, a União Federal apresentou uma cronologia da cadeia dominial da Marambaia destacando: 1) 1905 - adquirida pela União Federal; 2) 1939 - parte da ilha entregue a Fundação Abrigo Cristo Redentor para a construção da Escola de Pesca; 3) 1971 - através do Decreto $n^{\circ} 88.224$ de 12 de fevereiro de 1971, a administração da ilha foi passada para o Ministério da Marinha. Em resumo, por conta disso, durante o período de 1905 até 1971 "várias pessoas invadiram e ocuparam a Ilha da Marambaia", destacando que em nenhum caso a União Federal, "quer pela Fundação Cristo Redentor, quer pela Marinha", estabeleceu qualquer tipo de relação jurídica com os moradores. $^{25}$

Em 20 de março de 1997, dona Zenilda compareceu sozinha para a audiência de reintegração de posse marcada pela juíza da $29^{a}$ Vara Federal, dra. Simone Schreiber, sendo nomeado como seu advogado para tal audiência Marcelo Feijó Chalréo. A União Federal estava representada pelo procurador Ivo Henê Fernandes Bechara. A magistrada indagou dona Zenilda sobre a possibilidade de ela desocupar voluntariamente o imóvel em questão. O defensor respondeu que "em vista da longevidade da posse" deveria ser examinado o "fenômeno da aquisição por usucapião" chamando a atenção para o fato de que a União

${ }^{24}$ Processo $n^{\circ} 96.0007682-0$, pp. 2-5.

25 Processo no $96.0007682-0$, pp. 2-5 
Federal mencionava a "reincorporação do bem público ao seu patrimônio em 1971", sendo que muito antes disso a ré, "por si e por seus antepassados" já vivia no território. ${ }^{26}$ Embora a União Federal tenha reiterado o pedido de desocupação liminar do imóvel, a juíza decidiu que:

Considerando que a posse da ré pelo que esta sendo inicialmente alegado já tem no mínimo 65 anos, uma vez que desde que a mesma nasceu seus pais já residiam no imóvel objeto da presente reintegração, a situação está de tal modo consolidada que só por essa razão já não estaria este juízo apto a autorizar a desocupação liminar. ${ }^{27}$

A favor de dona Zenilda também deferiu a gratuidade de justiça, solicitando à Ordem dos Advogados do Brasil que, no prazo de dez dias, indicasse um advogado dativo. Além disso, intimou o IPHAN (Instituto do Patrimônio Histórico e Artístico Nacional) a informar, no prazo de 15 dias, se o objeto da ação "enquadrava-se nas especificidades" do art. 68 do Ato das Disposições Constitucionais Transitórias - ADCT, da Constituição Federal de 1988, que garantia que "aos remanescentes das comunidades dos quilombos que estejam ocupando suas terras, é reconhecida a propriedade definitiva, devendo o Estado emitir-lhes os títulos respectivos". ${ }^{28}$ Em 29 de abril de 1997, foi expedido pela 29a Vara Federal o ofício n ${ }^{\circ}$ 359/97 ao coordenador do IPHAN, Cyro Illydio C. de Oliveira Lyra. ${ }^{29}$ No dia 17 de julho de 1997, através do ofício ${ }^{\circ}$ 042/97, a procuradora jurídica chefe do IPHAN, Sista Souza dos Santos, respondeu à juíza, encaminhando o "Relatório de Pesquisa" de 9 de julho de 1997, elaborado pelo técnico Joaquim Alcides Ribeiro, do quadro funcional do IPHAN. Na sua conclusão, apontou que "até 1851 não houve quilombo instalado" na "praia da Armação". ${ }^{30}$ Para responder se

26 Processo $\mathrm{n}^{\circ}$ 96.0007682-0, assentada. 20 mar. 1997, pp. 28-9.

27 Processo $n^{\circ} 96.0007682-0$, assentada. 20 mar. 1997, p. 28

28 Processo ${ }^{\circ}$ 96.0007682-0, assentada. 20 mar. 1997, p. 29.

29 Processo n ${ }^{\circ}$ 96.0007682-0, Ofício no 359/97-G. "Pelo presente, a fim de instituir os autos da Ação de Reintegração de Posse $n^{\circ}$ 96.0007682-0, proposta pela União Federal contra Zenilda Soares Felicíssimo, determino a V. Sa. que, no prazo de 15 dias, informe a este juízo se a área em que se localiza o imóvel $n^{\circ} 02$ da Praia da Armação na Ilha da Marambaia, enquadra-se nas especificidades do art. 68 do ADCT da Constituição Federal de 1988”. 29 de abril 1997.

${ }^{30}$ Processo no 96.0007682-0, Ofício no 042/97 - GAB/RJ/ PROJUR/ IPHAN - "Em atendimento ao ofício indicado na epígrafe, pelo qual Vossa Excelência, visando instruir os autos da Ação de Reintegração de Posso proposta pela União Federal em face de Zenilda Soares Felicíssimo 
a Ilha da Marambaia, em particular a Praia da Armação foi palco da "organização de quilombo" o técnico do IPHAN adotou três procedimentos: 1) pesquisa de fontes documentais, bibliográficas e arquivísticas; 2) entrevista com pesquisadores e estudiosos do assunto; e 3) tentativa de contato com a Marinha Brasileira. Em nenhum momento foi cogitada, por exemplo, a possibilidade da realização de entrevistas com a própria comunidade. ${ }^{31}$

O técnico Ribeiro informou que em 5 de julho de 1997 foi enviado ao $1^{\circ}$ Distrito Naval o ofício $\mathrm{n}^{\circ} 25 / 97$ solicitando apoio no sentido do “... acesso a fontes... [e] possível acesso ao local...". O ofício, porém, não foi respondido. Ele garantiu também que foram estabelecidos contatos com Márcia Amantino e Flávio dos Santos Gomes, “cujos trabalhos - teses de mestrado, doutorado e livro publicado - têm por objeto a problemática dos quilombos". Segundo ele, ambos revelaram desconhecimento quanto à possível existência de quilombos na Marambaia. ${ }^{32}$ Detalhe: não mencionou como, quando e em que condições foram feitas tais consultas para respaldar seu teor e conteúdo. E nem mencionou ter consultado os escritos desses estudiosos num exame detalhado de temas e fontes. No parecer enviado à juíza, asseverou em seu relatório técnico que a extensão do território da Marambaia "não favorece a existência de esconderijos seguros e a mobilidade tática de grupos aquilombados" por ser uma região de passagem constante de embarcações. E que a vinda de escravos do continente para a ilha seria pouco provável "face às dificuldades de travessia". Considerava assim que "qualquer ajuntamento de quilombolas teria sido prontamente reprimido" pelos fazendeiros ou mesmo pelo poder público que certamente "não teria muita dificuldade

(processo $\mathrm{n}^{\circ}$ 96.0007682-0), que determinou ao Senhor Coordenador da $6^{\mathrm{a}}$ Coordenação Regional deste Instituto que informasse a esse Juízo se a área em que se localizava o imóvel n ${ }^{\circ} 02$, da Praia da Armação, na Ilha da Marambaia, se enquadra nas especificidades do art. 68 do Ato das Disposições Constitucionais Transitórias, apresento-lhes o anexo "Relatório de Pesquisa" e o Anexo "Notas", firmado em 9 de julho de 1997, pelo Técnico Joaquim Alcides Ribeiro, Pesquisador do Quadro Pessoal desta Autarquia, matrícula n ${ }^{\circ}$ 0224074, cuja conclusão aponta que "até 1851 não houve quilombo instalado" na "praia da Armação". 17 de julho 1997.

31 Relatório de Pesquisa do IPHAN sobre a possível existência de quilombo na praia da Armação, Ilha da Marambaia. Elaborado por Joaquim Alcides Ribeiro em 9 de julho de 1997.

32 Relatório de Pesquisa do IPHAN. 
em prender os negros em situação de cerco natural, proporcionado pelas próprias condições geográficas" da ilha. Ao buscar subsídios para seu argumento, o técnico do IPHAN citou uma documentação da Auditoria Geral da Marinha do ano de 1851, quando, diante de uma denúncia de tráfico de escravos, "o chefe de polícia Hermenegildo José Gonçalves" chegou à Marambaia acompanhado de uma "força policial e militar". Após dois dias vasculhando a região, apreenderam 199 africanos. A partir de tal evidência, considerou que se houvesse uma comunidade quilombola estabelecida no local "certamente teria sido encontrada por ocasião destas batidas". ${ }^{33}$ Em suma, assim estaria resumida pelo parecer de um técnico do IPHAN mobilizado pela Justiça - a história de ocupação e posse da ilha da Marambaia por uma população de remanescentes quilombolas que reivindicava direitos constitucionais. Para ele não houve quilombo (e, portanto, não havia possibilidade de existir uma comunidade remanescente que ele sequer consultou), baseado numa consulta incompleta da documentação, numa parca coleta de evidências e consulta informal a especialistas.

A questão não parou aí e a balança continuava a pesar para o lado da população da Marambaia. O episódio abria espaço para a expulsão agora baseada numa decisão judicial - de vários moradores que se mobilizavam por direitos constitucionais fundamentados na identidade de remanescentes de quilombolas. E dona Zenilda não foi a única a ser processada pela União Federal. Foram também acionadas judicialmente as seguintes famílias de moradores: Beatriz Maria Inocêncio (1996), Paulo Vicente Machado (1996), Sebastião Sant'Ana (1996), Joel Rosa de Lima Filho (1997), Porfíria Joaquim Machado (1998), Benedito Augusto Juvenal (1998), Benedito Santana (1998), Eugênia Eugênio Barcellos (1998), Elcio Santana (1998), Eraldo Oliveira dos Reis (1998) e Sebastiana Camilla Henriqueta de Lima (1998).

No final da década de 90 outros personagens entrariam em ação. Mais polêmicas e argumentos. A Comissão Pastoral da Terra (CPT) de

33 Relatório de Pesquisa do IPHAN. O chefe de polícia chamava-se Bernardo Azambuja. Ver processo: Arquivo Nacional do Rio de Janeiro (doravante ANRJ), Auditoria Geral da Marinha. Microfilme 117-2001. Processo de presa feita na Ilha da Marambaia de 199 africanos que constava terem sido recentemente ali desembarcados. Rio de Janeiro, 1851. 
Itaguaí, com o apoio do padre Galdino Canova ${ }^{34}$ organizou o dossiê "Povos da Terra - Povos do Mar - Ilha da Marambaia: do tráfico de escravos ontem, ao despejo de famílias pescadoras hoje". Assinado pelo padre Milton da Silva Fontella, o principal objetivo deste dossiê (1998) era tornar público - com denúncias visando à mobilização de entidades e órgãos - o que estava ocorrendo com os moradores da Marambaia. ${ }^{35} \mathrm{O}$ dossiê era constituído de artigos (recortes) publicados pela imprensa local e nacional e de uma carta aberta endereçada ao então presidente da República, Fernando Henrique Cardoso, que destacava em seu conteúdo:

Desde o século passado, nossos pais moravam nesta ilha, a maioria deles trazidos como escravos da África, para passarem a quarentena nesta ilha, antes de serem distribuídos [...] nas muitas fazendas do interior do estado, até o Vale do Paraíba. ${ }^{36}$

Reacenderia um debate, com vários usos e sentidos, sobre o direito constitucional dos descendentes quilombolas, história, memória, políticas públicas e cidadania.

A questão jurídica, embora morosa, também avançava entre capítulos e protagonistas conformando novas arenas políticas. Das outras famílias acionadas judicialmente, apenas a de dona Sebastiana Camilla Henriqueta de Lima teve seu imóvel reintegrado a União Federal em 19 de dezembro de 2001. Ela que nasceu na Ilha da Marambaia, em 1918, foi obrigada a abandonar sua casa aos 83 anos de idade. No seu processo há dois pareceres expedidos pelo procurador do Ministério Público Luiz Claudio Pereira Leiva, e encaminhados à juíza da 30ª Vara Federal e ao desembargador do Tribunal Regional Federal em meados de dezembro de 2001. Esses pareceres bateram na mesma tecla do parecer do

${ }^{34}$ Padre Galdino se ofereceu diversas vezes como testemunha na ação de reintegração de posse ajuizada por pela União Federal contra dona Eugênia Eugênio Barcelos. Processo n ${ }^{\circ}$ 98.0013915-0. 27 Vara Federal - Rio de Janeiro. 24 de jun. 1998.

35 Estão anexadas ao dossiê organizado pela Comissão Pastoral da Terra as seguintes notícias: 1) Editorial jornal Paratodos, n. 10, 1998; 2) "Marinha manterá Ilha da Marambaia inacessível", artigo de Luiz Carlos Cascan para o jornal O Globo de 19 de abril de 1998; 3) "Luta para ficar na Marambaia" artigo de Rosayne Macedo para o jornal O Dia de 02 de agosto de 1998.

${ }^{36}$ Carta ao presidente da República Fernando Henrique Cardoso enviada pelos moradores da Ilha da Marambaia. A carta esta anexada ao dossiê organizado pela Comissão Pastoral da Terra. 
técnico do IPHAN. O procurador Leivas destacou que, como representante do Ministério Público, não "poderia deixar passar impune essa verdadeira falsificação da história" que tentava demonstrar a existência de "um quilombo junto ao alcance da voz de um dos maiores mercados de escravos da Província Fluminense, numa Ilha!". Para ele "em nenhum momento existiram quilombos ou quilombolas na Marambaia, onde seriam presa fácil do comendador Breves" e "seria um absurdo que esses escravos procurassem fugir para o morro isolado, numa ilha, onde seriam facilmente apresados, cercados de mar por todos os lados". Enfim, "a tese da existência de um quilombo na Marambaia se constitui, portanto, em um atentado grosseiro à História Pátria”. Para sustentar sua argumentação jurídica, Leivas recorreu à definição de quilombo no Dicionário Enciclopédico Larousse (1980): "casa ou lugar no mato onde se refugiam os escravos fugidos". Além do dicionário, se baseou nas citações do, segundo ele, "insuspeito" Edison Carneiro. Partindo de uma análise culturalista, Carneiro interpretaria o "quilombo" como um "esforço contra-aculturativo, uma resistência à aculturação européia a que eram submetidos os escravos nas senzalas". No final, Leivas lançaria a indagação: "como seria possível constituir-se naquela área restrita, cercada de mar por todos os lados, sem recursos próprios, um quilombo?"37

No campo do judiciário a batalha não estava perdida. Surgiriam, em reação, os pareceres de Daniel Sarmento, procurador do Ministério Público. Ele e a procuradora Mônica Campos da Ré assumiram uma posição contraria a de Leivas. Imediatamente, ajuizaram uma Ação Civil Pública, em 14 de fevereiro de 2002, contra a União Federal e contra a Fundação Cultural Palmares. Esta última obrigava a finalização do processo administrativo de titulação da comunidade da Marambaia como remanescente de quilombo, de acordo com o Decreto 3912 de 10 de setembro de 2001. ${ }^{38}$ Quanto a União Federal, solicitavam à mesma “tole-

37 Processo no $98.0007738-3$ - Ação de Reintegração de Posse ajuizada pela União Federal contra Sebastiana Camilla Henriqueta de Lima - Ministério Público Federal - 17 de dez. 2001, pp. 51-8.

38 Decreto $\mathrm{n}^{\mathrm{o}} 3912$ de 10 de setembro de 2001 - Regulamenta as disposições relativas ao processo administrativo para identificação dos remanescentes das comunidades dos quilombos e para o reconhecimento, a delimitação, a demarcação, a titulação e o registro imobiliário das terras por eles ocupadas. 
rar a permanência dos integrantes da comunidade negra da Marambaia dentro das áreas que ocupam na citada ilha" e não mais "adotar qualquer medida visando à retirada dos mesmos, ou a destruição ou danificação de suas casas e construções" ${ }^{39} \mathrm{Na}$ avaliação jurídica crítica de Sarmento, o posicionamento do Estado brasileiro com relação à comunidade remanescente de quilombo da Marambaia "beira a esquizofrenia":

Enquanto a Fundação Cultural Palmares, integrante do Governo Federal, estuda a identificação do grupo étnico como remanescente de quilombo, visando à garantia do seu direito de propriedade sobre a terra ocupada (art. 68 ADCT), bem como a proteção da sua cultura (art. 215, $\S 1^{\circ}$ e $216, \S 5^{\circ}$ da CF), a União Federal, através da Marinha e da AGU, trata de dizimar a mesma comunidade, asfixiando-a com restrições que inviabilizam a continuidade do seu modo tradicional de vida e expulsando seus membros das terras imemorialmente ocupadas! $!^{40}$

O século XXI começa e as novas posições do Ministério Público acabam por mobilizar mais aliados e discursos. A questão dos direitos constitucionais das comunidades quilombolas já tinha assumido uma posição relevante no debate sobre o acesso a terra, a políticas de reparação, inclusão e erradicação da desigualdade racial, inclusive com a criação de órgãos com status de ministério (a SEPPIR). Sarmento "ao tomar conhecimento do problema, solicitou a Koinonia - Presença Ecumênica e Serviço", uma organização não governamental (ONG), a elaboração de um relatório parcial, "visando à eventual caracterização da comunidade negra da Ilha da Marambaia, como remanescente de quilombo". Nessa época, a equipe desta ONG era coordenada pelo antropólogo José Maurício Arruti. Suas ações e as desta entidade já estavam em curso através do Programa Egbé Territórios Negros (1994), que atendia terreiros de candomblé e comunidades remanescentes de quilombo oferecendo "capacitações técnicas a partir de conhecimentos tradicionais das comunidades, diálogos para a superação da intolerân-

39 Processo no 2002.5111000118-2 - Ação Civil Pública -Ministério Público Federal. 14 de fev. 2002, pp. 3-20.

40 Processo no $^{\circ}$ 2002.5111000118-2 - Ação Civil Pública -Ministério Público Federal. 14 de fev. 2002, pp. 5-6. 
cia religiosa, assessoria jurídica, educativa e defesa de direitos". ${ }^{41}$ Foi realizado um levantamento e um relatório que concluiu que a comunidade da Marambaia enquadrava-se "com perfeita coerência" no modelo sociológico das "terras de uso comum" e das "terras de preto", ${ }^{42}$ destacando haver um "consenso largamente documentado" de que o termo "remanescente de quilombos" consiste em uma categoria jurídica nova, "que não encontra perfeita correspondência na categoria histórica dos quilombos conforme definido pela parca historiografia sobre o tema" ${ }^{43}$

Mais levantamentos e pesquisas etnográficas ganharam curso visando à certificação da comunidade da Marambaia como remanescente de quilombo. Constituiu-se um denso e completo estudo como parte do processo administrativo para o reconhecimento e titulação da comunidade como remanescente de quilombo. Esta pesquisa foi igualmente coordenada pelo antropólogo Arruti, sendo o seu relatório técnico-científico, um laudo antropológico, entregue a Fundação Cultural Palmares em 2003. ${ }^{44}$ Contou com a participação de vários pesquisadores, através de convênios com os seguintes grupos: 1) NRA - Núcleo de Referência Agrária da Universidade Federal Fluminense (Departamento de História); 2) NUFEP - Núcleo Fluminense de Estudos e Pesquisa da Universidade Federal Fluminense (Departamento de Antropologia). As pesquisas no NRA foram coordenadas pela historiadora Márcia Motta e contou com o apoio de Priscilla Amaral. ${ }^{45}$ Pelo NUFEP, fizeram parte

${ }^{41}$ Koinonia - Presença Ecumênica e Serviço. Programas - Egbé Territórios Negros. Rio de Janeiro, Disponível em: <www.koinonia.org.br/programas-egbe.asp> Acesso em 18 de maio de 2012. Para mais informações sobre o Programa Egbé Territórios Negros na Ilha da Marambaia ver: Estela Martini Willeman, "Marambaia: "Ilha subversiva". Múltiplos aspectos do processo de formação de identidade no "território negro" remanescente de quilombo" (Dissertação de Mestrado, Pontifícia Universidade Católica, 2007).

42 Alfredo Wagner Berno de Almeida, "Terras de preto, terras de santo, terras de índio: posse comunal e conflito", Humanidades, v. 15 (1987), pp. 42-9.

43 Processo no 2002.5111000118-2 - Ação Civil Pública -Ministério Público Federal. 14 de fevereiro de 2002, p. 9.

${ }^{44}$ José Arruti (org.), Relatório técnico-científico sobre a comunidade remanescente de quilombo da Ilha da Marambaia - Município de Mangaratiba (RJ), Rio de Janeiro: Koinonia / Fundação Cultural Palmares, 2003.

45 Ver: Márcia Motta, Nas fronteiras do poder. Conflito e direito a terra no Brasil do século XIX, Rio de Janeiro: Arquivo Público do Estado do Rio de Janeiro/Vício de Leitura, 1988; Márcia Motta (org.), Dicionário da Terra, Rio de Janeiro: Civilização Brasileira, 2005; Márcia Motta, "Ilha da Marambaia: história e memória de um lugar", in Elione Guimarães \& Márcia Motta 
da pesquisa: Bruno Leipner Mibielli, Eduardo Tavares Paes, Fábio Reis Mota, Lênin dos Santos Pires, e os antropólogos Roberto Kant de Lima e Ronaldo Joaquim da Silveira Lobão. Pela equipe de Koinonia, além de Arruti, fizeram parte da pesquisa: Alessandra Tosta, Ana Gualberto, Jefferson Gonçalves Correia, Mariza Rios e Sônia Almeida.

É interessante notar - a despeito da defesa dos territórios étnicos da comunidade da Marambaia e da construção de argumentos que se contrapunham aos relatórios do IPHAN e pareceres judiciais contrários - os usos e sentidos sobre a história dos quilombos no Brasil. No primeiro capítulo do relatório, "Sobre o conceito remanescente de quilombos e sua aplicação à comunidade de ilhéus da Marambaia", o antropólogo Arruti apresentou uma reflexão sobre os "usos históricos" do termo quilombo e concluiu com a "sua generalização pela geografia e história do país" que, "combinada ao franco desconhecimento objetivo sobre sua realidade histórica, fez dela esse tipo de evento pronto a reapropriações mitologizantes" e cujas implicações simbólicas tenderam a obscurecer as outras que lhes eram vizinhas, mas talvez mais estritamente historiográficas, entre as quais as relativas às condições que estimulavam a fuga e a constituição de quilombos, as táticas de defesa e repressão aos quilombos, sua demografia e economia e suas relações com a sociedade envolvente. ${ }^{46}$

Arruti apresentou, ainda, as diversas abordagens interpretativas sobre quilombo desde Nina Rodrigues até a ressemantização do termo pela Constituição de 1988, se baseando nas formulações do antropólogo Alfredo Wagner. Repetindo a avaliação do seu relatório parcial sobre o que denominou "parca historiografia sobre o tema", silenciou completamente sobre vários estudos, inclusive alguns que já demonstravam a existência de quilombos na Marambaia e indicavam fontes sobre isso. Tal perspectiva aparece no capítulo 3, "Percurso Histórico dos ilhéus da Marambaia (1856-2003)", ${ }^{47}$ no qual, para descrever a Ilha da Ma-

(org.), Campos em disputa. História Agrária e companhia (São Paulo: Annablume, 2007), v.1. p. 295-317; Márcia Motta, "Brecha negra em livro branco: Art. 68, remanescentes de quilombos e grilagem no Brasil", in Sônia Regina de Mendonça (org.), Estado e historiografia no Brasil (Niterói: EDUFF, 2006), v.1, pp. 231-55.

46 Motta, "Brecha negra em livro branco", p. 18.

47 Motta, "Brecha negra em livro branco", pp. 92-156 
rambaia, o município de Mangaratiba e a trajetória do comendador Breves, utiliza artigos e memórias produzidos por Renato Almeida, Assis Chateubriand, Geremário Dantas, Luis Ascendino Dantas, Agripino Grieco, Clodomiro Vasconcelos e Oliveira Vianna, todos publicados em uma edição comemorativa ao "Bi-Centenário da introdução do cultivo do café no Brasil", em 15 de outubro de 1927, no período carioca $O$ Jornal. ${ }^{48}$ Surpreende, em função da importância para o seu argumento, o silêncio sobre a historiografia da escravidão, da economia própria dos escravos, dos quilombos, da família escrava e do pós-Abolição escrita por Stuart Schwartz, Maria Helena Machado, João Reis, Eduardo Silva, Marcus Carvalho, Bert Barickman, Manolo Florentino, Guilhermo Palácios, Eurípedes Funes, Eduardo Silva, Carlos Magno Guimarães, Ciro Flamarion, Silvia Lara, Hebe Mattos, Ana Lugão Rios, Flávio Gomes e Robert Slenes. ${ }^{49}$ Explorou muito pouco as referências (indíci-

48 Esses são os artigos que o Arruti utilizou. Todos estão publicados nessa edição especial do periódico O Jornal de 15 de out de 1927. Renato Almeida, "Mangaratiba, terra de begônias"; Assis Chateubriand, "Um viveiro morto da mão-de-obra negra para o cafezal - Impressões vividas de uma visita a fazenda do comendador Joaquim José de Souza Breves no pontal da Marambaia"; Geremário Dantas, "O café na cidade do Rio de Janeiro"; Luis Ascendino Dantas, "São João Marcos da região do Campo Alegre: preeminência do plantio do café 1730-Resumo Histórico"; Agripino Grieco, "O maior dos Breves: impressionante figura de gentilhomen rural"; Agripino Grieco, "Pelo estado do Rio, da montanha ao mar"; Clodomiro Vasconcelos, "As estradas antigas do transporte do café no estado do Rio"; Oliveira Vianna, "Distribuição geográfica do cafeeiro no estado do Rio de Janeiro"; Oliveira Vianna, "Hegemonia no Vale do Parahyba": Rio de Janeiro, O Jornal, 15 de outubro de 1927.

49 Ver: Bert J. Barickman, "“A Bit of Land, Wich They Call Roça': Slave Provision Grounds in the Bahia Recôncavo, 1780-1860", Hispanic American Historical Review, v. 74, n. 4 (1996), pp. 64987; Idem, “As cores do escravismo: escravistas 'pretos', 'pardos' e 'cabras' no Recôncavo baiano, 1835". População e Família, v. 2, n. 2 (1999), pp. 7-62; Ciro Flamarion S Cardoso, Escravo ou camponês ? O procampesinato negro nas Américas, São Paulo: Brasiliense, 1987; Marcus de Carvalho, "O quilombo do Malunguinho, o rei das matas de Pernambuco", in João José Reis e Flávio dos Santos Gomes, Liberdade por um fio. História dos Quilombos no Brasil. São Paulo: Companhia das Letras, 1996, pp. 407-32; Hebe Mattos e Ana Maria Lugão Rios, "O pós-abolição como problema histórico: balanços e perspectivas", Topoi, v. 5 (2004), pp. 170-98; Idem, Memórias do cativeiro: família, trabalho e cidadania no pós-abolição, Rio de Janeiro: Civilização Brasileira, 2005; Hebe Maria Mattos de Castro, Ao sul da História. Lavradores pobres na crise do trabalho escravo, São Paulo: Brasiliense, 1987; Idem, "Políticas de reparação e identidade coletiva no mundo rural: Antônio Nascimento Fernandes e o Quilombo São José", Revista de Estudos Históricos, n. 37 (2006), pp. 167-89; Idem, "Remanescentes das comunidades dos quilombos": memórias do cativeiro e políticas de reparação no Brasil", Revista da USP, n. 68 (2006), pp. 10411; Iraci del Nero da Costa, Arraía-Miúda. Um Estudo sobre os não-proprietários de escravos no Brasil, São Paulo: MGSP Editores, 1992; João Luís Ribeiro Fragoso e Manolo G. Florentino, "Marcelino, filho de Inocência Crioula, neto de Joana Cabinda: um estudo sobre famílias escravas em Paraíba do Sul (1835-1872)", Estudos Econômicos, v. 17, n. 2 (1987), pp. 151-73; Flávio 


\section{os) e cotejamento de fontes que ajudariam na argumentação das rela- ções entre escravidão e quilombos, uma vez que o tema central era a}

dos Santos Gomes e João José Reis (orgs.), Liberdade por um fio. História dos Quilombos no Brasil, São Paulo: Companhia das Letras, 1996; Eurípedes Funes, “"Nasci nas matas, nunca tive senhor". História e memória dos mocambos do Baixo Amazonas" (Tese de Doutorado, USP, 1995); Idem, “"Nasci nas matas, nunca tive senhor'. História e memória dos mocambos do Baixo Amazonas", in Reis e Gomes, Liberdade por um fio, pp. 467-97; Flávio dos Santos Gomes, "'O campo negro` de Iguaçu: escravos, camponeses e mocambos no Rio de Janeiro (1812-1883)", Estudos Afro-Asiáticos, n. 25 (1993); Idem, "Ainda sobre os quilombos: repensando a construção de símbolos de identidade étnica no Brasil", in Elisa Reis, Maria Hermínia Tavares de Almeida e Peter Fry (orgs.), Política e Cultura. Visões do passado e perspectivas contemporâneas (São Paulo: ANPOCS/Hucitec, 1996), pp. 197-221; Idem, "Nos mundos da escravidão: escravos, camponeses e quilombolas no Rio de Janeiro do Século XIX", Cadernos UFS: HISTÓRIA, Programa de Documentação de Pesquisa Histórica, Universidade Federal de Sergipe, EDUFS, 1996; Idem, "Slavery, Black Peasants and Post-emancipation Society in Brazil (Nineteenth Century Rio de Janeiro)", Social Identities, v. 10, n. 6 (2004), pp. 735-56; Idem, A hydra e os pantânos. Mocambos, quilombos e comunidades de fugitivos no Brasil escravista (sécs. XVII-XIX). São Paulo: Polis/UNESP, 2005; Carlos Magno Guimarães, "Quilombos e brecha camponesa. Minas Gerais (Século XVIII)". Revista do Departamento de História, n. 8 (1989), pp. 139-63; Idem, "Quilombos: classes, política e cotidiano (Minas Gerais no século XVIII" (Tese de Doutorado, USP, 1999); Idem, Uma negação da ordem escravista. Quilombos em Minas Gerais no século XVIII. São Paulo: Icone Editora, 1988; Herbert S. Klein, "Os homens livres de cor na sociedade escravista brasileira", Revista DADOS, n. 17 (1988), pp. 3-27; Maria Helena Pereira Toledo Machado, "Em torno da autonomia escrava : uma nova direção para a história social da escravidão", Revista Brasileira de História, ANPUH/Marco Zero, v. 8, n. 16 (1988); Idem, "Vivendo na mais perfeita desordem: os libertos e o modo de vida camponês na província de São Paulo do século XIX", Estudos Afro-Asiáticos, n. 25 (1993); Idem, O plano e pânico. Movimentos sociais na década da Abolição. Rio de Janeiro: EDUFRJ/EDUSP, 1994; Guilhermo Palácios, "Campesinato e escravidão: uma proposta de periodização para a história dos cultivadores pobres livres no Nordeste Oriental do Brasil, C. 1700-1875", DADOS, v. 30, n. 3 (1987); Idem, Cultivadores libres, Estado y crisis de la esclavitud en Brasil en la epoca de la Revolución Industrial, El Colégio de México: Fondo de Cultura Económica, 1998; João José Reis, "Escravos e coiteiros no quilombo do Oitizeiro, em 1806", in Reis e Gomes (orgs.), Liberdade por um fio, pp. 332-72; Idem, "Quilombos e revoltas escravas no Brasil. 'Nos achamos em campo a tratar da liberdade"”, Revista USP, v. 28 (1995-1996), pp. 100-26; Idem, "Resistência escrava na Bahia. "Poderemos brincar, folgar e cantar ...": O protesto escravo na América", Afro-Ásia, n. 14 (1993), pp.107-22; Stuart B. Schwartz, "Mocambos, quilombos e Palmares: a resistência escrava no Brasil colonial". Estudos Econômicos, v. 17, número especial (1987), pp. 61-88; Idem, "Resistance and Accommodation in Eighteenth-century Brazil: The Slaves View of Slavery". Hispanic American Historical Review, v. 57, n. 1 (1977), pp. 69-81; Idem, Slaves, Peasants, and Rebels. Reconsidering Brazilian Slavery, Urbana: University of Illinois Press, 1992; Idem, Escravos, Roceiros e Rebeldes. São Paulo: Ed. São Francisco, 2001; Eduardo Silva, "A função ideológica da brecha camponesa", in João José Reis e Eduardo Silva, Negociação e conflito: a resistência negra no Brasil escravista (São Paulo: Companhia das Letras, 1989), pp. 22-31; Slenes, Robert W . Slenes, "Na senzala, uma Flor: 'as esperanças e as recordações' na formação da família escrava, Rio de Janeiro; Nova Fronteira, 1999; Idem, "Histórias do Cafundó", in Carlos Vogt e Peter Fry (com a colaboração de Robert Slenes), Cafundó. A África no Brasil. Linguagem e sociedade (São Paulo: Companhia das Letras, 1996), pp. $37-102$. 
longevidade de uma comunidade rural negra com direitos étnicos consagrados pela história e experiência da escravidão e no pós-Abolição, reconhecidos constitucionalmente e defendidos por movimentos sociais dos próprios quilombolas,

O que faltou de referências historiográficas no relatório coordenado por Arruti sobrou de densidade na pesquisa etnográfica, informando sobre os sentidos do parentesco, usos da terra e de recursos naturais e o movimento da população no século XX. Com um estudo sólido, confirmou todos os dados apresentados anteriormente, recolhidos em processo de pesquisa: "sugerimos vivamente o reconhecimento oficial da comunidade de ilhéus da Marambaia (RJ), nos termos do artigo 68 (ADCT), como comunidade remanescente de quilombo". Mas a luta continuou, e na mão dos antropólogos/sociólogos, agora com a ajuda de arqueólogos. No mesmo ano de 2003, a Marinha apresentou a sua contestação ao relatório da equipe coordenada por Arruti. Encomendou um estudo ao Laboratório de Antropologia Biológica da Universidade do Estado do Rio de Janeiro (UERJ). O trabalho foi coordenado pela professora Cléia Schiavo Weyrauch e contou com a participação de Ivan Francisco da Silva, Alexander Noronha de Albuquerque e da professora Nanci Vieira de Oliveira, arqueóloga que efetuou coletas na área para eventuais análises e datações. O relatório coordenado por Cléia Schiavo questionou a argumentação da utilização da ilha como porto clandestino para desembarque de africanos. Desconsiderando a vasta documentação - relatórios policiais e ministeriais no Arquivo Público do Estado do Rio de Janeiro e o acompanhamento sistemático da imprensa na época através do Jornal do Commércio - concluiu que a memória da população da Marambaia “apresenta-se através de lembranças vagas, de modo geral cheia de equívocos", finalizando que "a Ilha da Marambaia certamente não alcançou institucionalizar uma cultura de resistência nos moldes de outras comunidades brasileiras. ${ }^{50}$ Para um estudo científico, as conclusões sumárias deste relatório impressionam. Sobre a história propriamente da Marambaia, da escravidão e do desembarque de africanos, um profundo silêncio acabando por concluir aquilo que certa-

${ }^{50}$ Cléia Schiavo Weyrauch, Projeto Marambaia. Rio de Janeiro: UERJ, 2003. 
mente a Marinha esperava: a população atual da ilha, a escravidão do passado, as comunidades remanescentes de quilombo e os quilombos antigos eram fenômenos absolutamente incompatíveis nos termos históricos, antropológicos e agora arqueológicos no tocante a Marambaia.

Mais estudos e interlocutores se apresentaram, envolvidos diretamente ou não na disputa judicial, agora explicitamente politizada e tornada cada vez mais pública. Evidências históricas, sempre esquecidas, se juntaram aos argumentos antropológicos esgrimidos para vários usos e interesses, ganhando desdobramentos. O conflito em torno da Marambaia, os direitos da sua população, as políticas públicas, as interpretações no campo do direito constitucional ganharam páginas e páginas (além de seminários e palestras) de estudos em vários programas de pós-graduação. ${ }^{51}$ Ainda no campo da Antropologia, destaca-se a dissertação de Fábio Reis Mota, que analisou a construção da identidade quilombola entre os moradores da Marambaia. ${ }^{52}$ Já na área de Educação, Vladimir Zamorano descreveu o funcionamento da Escola de Pesca Darcy Vargas durante o período de $1939-1970 .{ }^{53} \mathrm{Na}$ perspectiva do Di-

51 De acordo com levantamento realizado no Banco de Teses e Dissertações da CAPES para o período de 1987-2010, foram identificadas 12 teses e 41 dissertações que têm como tema a Ilha da Marambaia. As pesquisas envolvem vários campos de estudo: 1) veterinária; 2) ciência política; 3) antropologia; 4) geografia; 5) ciência e tecnologia de alimentos; 6) biologia animal, 7) biociências nucleares; 8) botânica; 9) microbiologia; 10) ecologia; 11) ciências sociais; 12) educação; 13) história; 14) serviço social; 15) zootecnia; 16) análise de bacias e faixas móveis; 17) evolução crustal e recursos naturais; 18) extensão rural; 19) ciências do mar; 20) oceanografia biológica; 21) biologia marinha; 22) ciências ambientais e florestais; 23) zoologia; 24) geologia. Muitos desses trabalhos podem ser encontrados no livro: D.S.D. Araújo, A.L. Peixoto, L.F.T. Menezes (orgs.). História Natural da Marambaia (Rio de Janeiro: Editora da Universidade Federal Rural do Rio de Janeiro/ Seropédica, 2005). Ver também: Lilian Cristina Bernardo Gomes, "Justiça seja feita: direito quilombola ao território" (Tese de Doutorado, Universidade Federal de Minas Gerais, 2009). Olívia Chaves Oliveira, "As possibilidades de novos rumos para a educação formal na Ilha da Marambaia - RJ" (Dissertação de Mestrado, Universidade Federal Rural do Rio de Janeiro, 2009); Juliana Santos Souza, "Sobre processos de mediação de conflitos. O caso da restinga da Marambaia" (Dissertação de Mestrado, Universidade Federal Fluminense, 2011); Daniel Ferreira Silva, "Ilha da Marambaia, RJ: atores externos, transformações econômicas e conflitos" (Dissertação de Mestrado, Universidade Federal de Viçosa, 2005).

${ }^{52}$ Fábio Reis Mota, "Nem muito mar, nem muita terra. Nem tanto negro, nem tanto branco: uma discussão sobre o processo de construção da comunidade remanescente de quilombos da Ilha da Marambaia/ RJ" (Dissertação de Mestrado, UFF, 2003); Idem, "Marambaia da terra, Marambaia do mar: conflitos, identidades e meio ambiente no estado do Rio de Janeiro" (Monografia de Graduação, UFF, 2001); Idem, "Cidadãos em toda parte ou cidadão à parte? Demandas de direitos e reconhecimento no Brasil e na França" (Tese de Doutorado, UFF, 2009).

53 Zamorano, "A antiga escola da Marambaia". 
reito, Aline Caldeira Lopes apresentou uma análise das ações de reintegração de posse ajuizadas pela União Federal em sua dissertação "Marambaia: processo social e direito". ${ }^{54} \mathrm{Na}$ História, com pesquisas arquivísticas de fôlego, destaque para os estudos de Daniela Yabeta que analisou a atuação da Auditoria Geral da Marinha contra o tráfico ilegal de africanos, especialmente na área da Marambaia entre 1850 e $1851^{55}$ e de Thiago Campos abordando as trajetórias dos comendadores José Joaquim e Joaquim José de Souza Breves para analisar a formação escravista que eles operaram. ${ }^{56}$

\section{Sobre as histórias dos quilombolas}

Nos debates contemporâneos sobre os direitos étnicos das comunidades quilombolas a terra, a ação (teórica e prática) dos antropólogos tem sido decisiva. ${ }^{57}$ Em parte, seguindo uma rica tradição acadêmica, os estudos sobre sociedades indígenas e também sobre as formas camponesas foram fundamentais na "tradução" pública das questões da iden-

${ }^{54}$ Aline Lopes, "Marambaia: processo social e judiciário" (Dissertação de Mestrado, UFRRJ/ CPDA, 2010).

55 Daniela Yabeta, "A capital do comendador".

${ }^{56}$ Lourenço, "O Império dos Souza Breves nos oitocentos".

57 Destacamos entre outros: Rosa Elizabeth Acevedo Marin e Edna M. Ramos Castro, Negros do Trombetas: etnicidade e história, Belém: NAEA/UFPA, 1991; Rosa Elizabeth Acevedo Marin, "Negros do Trombetas. Guardiões de matas e rios, Belém: UFPA, 1993; Alfredo Wagner Berno de Almeida, "Terras de preto, terras de santo, terras de Índio. Uso comum e conflito", in Edna M. R. Castro e Jean Habette (orgs.), Na trilha dos grandes projetos: modernização e conflito na Amazônia. Cadernos do NAEA/UFPa, n. 10 (1990); José Maurício Andion Arruti, "Etnias federais": o processo de identificação de "remanescentes" indígenas e quilombolas no Baixo São Francisco" (Tese de Doutorado, UFRJ, 2002); Maria de Lourdes Bandeira, Território negro em espaço branco: estudo antropológico de Vila Bela, São Paulo: Brasiliense, 1988; José Jorge de Carvalho (org.). O quilombo do Rio das Rãs: histórias, tradições e lutas, Salvador: CEAO/ EDUFBA, 1996; Neusa M. Mendes de Gusmão, Terra de pretos, terra de mulheres: terra, mulher e raça num bairro negro. Brasília: MEC/Fundação Cultural Palmares, 1996; Ilka Boaventura Leite (org.), Negros no Sul do Brasil: invisibilidade e territorialidade, Santa Catarina: Letras Contemporâneas, 1996; Anita M. de Q. Monteiro, Castainho: etnografia de um bairro rural de negros, Recife: Ed. Mansangana, 1985; Eliane Cantarino O'dwyer (org.), Terra de Quilombos, Rio de Janeiro: Associação Brasileira de Antropologia, 1995; Idem, Quilombo: identidade étnica e territorialidade, Rio de Janeiro: FGV/ABA, 2002; Renato da S. Queiroz, Caipiras negros no Vale do Ribeira: um estudo de antropologia econômica, São Paulo: FFLCH/ USP, 1993; Valdélio Santos Silva, "Rio das Rãs à luz da noção de quilombo", Afro-Ásia, n. 23 (1999), pp. 267-95; e Jean-François Véran, "Rio das Rãs: memória de uma `comunidade remanescente de quilombo", Afro-Ásia, n. 23 (1999), pp. 297-330. 
tidade étnica e dos territórios. Mesmo diante da posição contrária (com forte apoio de setores da mídia e alguns articulistas oportunistas) de determinados partidos políticos, parlamentares conservadores e ruralistas, há hoje uma definição consagrada - em parte recuperada por pesquisas etnográficas, modulações teóricas e a memória camponesa - de que é quilombola e remanescente de quilombo quem diz que é quilombola e remanescente de quilombo, a partir da sua história, identidade, territorialidade, uso da terra e recursos naturais, além da cultura material e imaterial. ${ }^{58}$ Também o quilombo e/ou a comunidade remanescente não foi e nem é um território isolado. Sempre houve conexões de produção e mercantilização de base camponesa, também com o caráter migratório, itinerante e nunca tão somente fixo. Tanto no passado do quilombo histórico como na realidade atual das comunidades remanescentes. Enfim, ontem e hoje os quilombos e/ou comunidades se encontravam e se encontram onde estavam ou estão os quilombolas. De ontem e de hoje.

Paradoxalmente, a despeito das suas revisões mais recentes, a historiografia da escravidão e do pós-Abolição ficou de fora deste debate. Não é difícil compreender tal exclusão, quiçá involuntária. Muitas vezes, algumas definições históricas (especialmente aquelas da le-

58 Sobre a auto-atribuição ver: 1) Decreto 4887 de 20 de novembro de 2003, regulamenta o procedimento para identificação, reconhecimento, delimitação, demarcação e titulação das terras ocupadas por remanescentes das comunidades dos quilombos de que trata o Art. 68 do Ato das Disposições Constitucionais Transitórias da Constituição Federal de 1988. O Art. $2^{\circ}$ considera como remanescente das comunidades quilombolas, grupos étnicos raciais, segundo critério de autoatribuição, com trajetória histórica própria, dotados de relações territoriais específicas, com presunção de ancestralidade negra relacionada com a resistência à opressão história sofrida. $\mathrm{O} \S 1^{\circ}$ do referido artigo $2^{\circ}$ determina que a caracterização das comunidades dos quilombos seja atestada mediante autodefinição da própria comunidade. 2) Convenção $\mathrm{n}^{\circ}$ 169 da Organização Internacional do Trabalho - OIT, de 07 de junho de 1989 - Convenção relativa aos povos indígenas e tribais em países independentes. Em seu Art. $1^{\circ}$ a Convenção aplica-se: a) aos povos tribais independentes, cujas condições sociais culturais e econômicas os distinguiam de outros setores da coletividade nacional, e que sejam regidos, total ou parcialmente, por seus próprios costumes ou tradições ou por legislação especial. O mesmo artigo determina que a autoidentificação como indígena ou tribal deva ser considerada critério fundamental para determinar os grupos aos que se aplicam as disposições da Convenção. 3) Decreto Legislativo $n^{\circ} 143$ de 20 de junho de 2002 - Aprova o texto da Convenção $n^{\circ} 169$ da Organização Internacional do Trabalho sobre os povos indígenas e tribais em países independentes 4) ADI 3239 movida pelo Partido da Frente Liberal (PFL), atual Democratas (DEM), solicita a inconstitucionalidade do Decreto 4887 de 20 de novembro de 2003. 
gislação colonial) sobre os quilombos eram usadas, por setores jurídicos e de contestação, contra os direitos que dezenas comunidades quilombolas contemporâneas reivindicavam. Era visto como lugar de fugidos, isolados e atomizados nas margens da sociedade escravista. Argumentava-se que um ou outro quilombo do passado teria sobrevivido posto que isolado e distante - até os dias atuais com suas comunidades e culturas. Há indicações de que nas contestações, em vários lugares e situações, os laudos antropológicos foram acusados de falta de comprovação histórica, documentos ou evidências do passado, para determinar uma comunidade remanescente em determinado local. De maneira invisível e ás vezes cifrada, produziu-se um isolamento entre antropólogos e historiadores no campo do conhecimento (empírico e teórico) e na definição de evidências (tipo passado ausente versus presente emergente) sobre as comunidades quilombolas atuais. Houve mais discursos paralelos e divergências do que conexões - que ajudariam - nestes debates. Inclusive uma clássica e importante literatura sobre os quilombos históricos de Clóvis Moura, Décio Freitas, Artur Ramos, Edison Carneiro e Roger Bastide foi completamente omitida sob alegação que eram interpretações que substancializavam as definições "frigorificadas" do passado escravista e colonial. Um leitura mais atenta da mesma verificaria que a realidade dos quilombos apontada nestes estudos mais clássicos já chamava atenção para a diversidade e complexidade do quilombo no passado, nunca limitado a uma definição única de ordem legal, e, portanto, ajudaria a pensar a realidade também complexa contemporânea. Talvez o que estivesse no "frigorífico" não eram as experiências do quilombo no passado, as interpretações dos historiadores ou as possibilidades analíticas clássicas, mas sim a disposição para operar na perspectiva inter e multidisciplinar com outras ferramentas metodológicas e áreas do conhecimento.

Certamente, na ânsia de ajudar as comunidades quilombolas, operou-se uma quase "corrida teórica" de obstáculos da autoridade acadêmica e intelectual sobre o tema. Enfim, um amplo desafio, intelectual, acadêmico, político e ideológico, foi abandonado enquanto possibilidade de mobilizar diversos estudos e pesquisadores da temática. As novas perspectivas da historiografia da escravidão e pós-Abolição, por 
exemplo, avançaram em abordagens para entender processos históricos envolvendo quilombos, defesas de direitos costumeiros a terra e à economia própria dos escravos ("roças"), gestação de populações camponesas ainda durante a escravidão e depois da Abolição, conectando experiências de quilombolas, ex-escravos, libertos e população negra e mestiça desde o século XVIII atravessando o XX e XXI. Houve, desde o final dos anos 90, um esforço de analise da diversidade da experiência histórica dos quilombos no Brasil. Em termos da história como disciplina, também foi acionada a ideia de um "campo negro", refletindo guardadas determinadas áreas, regiões, conformações sócio-econômicas e demográficas - sobre a tradição de quilombos (desde aqueles maiores até os pequenos grupos volantes) e suas complexas alianças, circunstanciais e permeadas de conflitos, com a sociedade envolvente. Ampliavam-se bases econômicas, autonomia e proteção através de verdadeiras redes de trocas, proteção e solidariedade junto a fazendas, povoados, feiras e vilas.

\section{O documento sobre o quilombo da Marambaia}

Paradoxalmente, o documento localizado sobre o quilombo da Marambaia não é novo. A referência explícita a ele aparece numa dissertação de mestrado de 1993 e numa publicação em livro em 1995. ${ }^{59}$ Estranhamente ficou desconhecido durante os debates e polêmicas envolvendo a comunidade nos anos 90 até praticamente os dias de hoje. Não se trata, embora de igual natureza, de mais um documento de polícia sobre a ação dos quilombos em determinado lugar e ação de repressão acionada sobre ele. Exatamente para a Marambaia, temos um exemplo da formação de quilombo que conectava expectativas de "direitos" de quilombolas e assenzalados. No final do ano de 1870, no interior da fazenda da Marambaia, pertencente ao comendador Souza Breves, localizada em Mangaratiba, sul da província fluminense, havia se aquilombado um grupo de escravos.

59 Dissertação entregue em novembro de 1992 e defendida em fevereiros de 1993: Flávio dos Santos Gomes "História de quilombolas. Mocambos e comunidades de senzalas. Rio de Janeiro, Séc. XIX" (Dissertação e Mestrado, Unicamp, 1995). Em fins de 1995, com o mesmo título e poucas mudanças, foi publicada pelo Arquivo Nacional. 
É interessante destacar o ritual da administração provincial, no sentido da ação das autoridades policiais, na produção de ofícios, petição, relatórios etc. Entre setembro e outubro de 1870, vários ofícios foram produzidos e autoridades locais, provinciais e imperiais se manifestaram. A coisa podia começar com uma simples denúncia, publicada nos jornais, que mobilizava as autoridades de polícia da província que acionava a força policial e local, alcançando o ministro da Justiça. Feito isso mais ofícios eram trocados cumprindo o ritual de volta. No caso da Marambaia, o ofício final do presidente de província ao ministro da Justiça dá praticamente o caso como solucionado. Denúncias sobre quilombos aparecem, as autoridades da província mobilizam tropas e expedições, resultando em repressão, prisão e investigação. No despacho final do ministro, após a ação de repressão, a conclusão é de que "não se encontrou vestígio algum de quilombo". O relatório do delegado de Polícia, que efetivamente realizou a diligência, é bem mais detalhado, posto que tenha participado tanto da repressão como da investigação. $\mathrm{O}$ delegado de Polícia de Mangaratiba e o major Antônio Luiz Rodrigues, que comandaram a expedição, destacaram vários itens. Comentam como receberam a denúncia no início de setembro e prepararam a expedição. Enfim, foi uma ação coordenada. A tropa, com 30 soldados, um número considerável, chegou à ilha de Marambaia numa madrugada e imediatamente cercou e invadiu a fazenda do comendador Breves. A ação ficou concentrada nas "senzalas da fazenda para onde se convergião [sic] todas as suspeitas de lá se acharem os fugitivos". Houve somente uma prisão, mas vários tiros foram disparados. Há evidências de resistência coletiva, e a repressão foi continuada para as matas em torno da fazenda. Tentava-se tanto prender os fugitivos como encontrar os quilombos que, ao que parece, acreditava-se existir. Enquanto o despacho do ministro foi rápido em afirmar "não se encontrou vestígio algum de quilombo", o delegado de polícia admitiu "não se encontrando também nessa[s] excursões quilombo algum, nem constando havê-los, a exceção dos vestígios de um que antecipadamente já tinha sido destruído pelos próprios fugitivos". Qual seja, haviam, sim, sido encontrado "vestígios", certamente ruínas de ranchos erguidos, de um quilombo que tinha sido destruído, quiçá abandonado pelos próprios fugitivos. Os vários ofícios foram convergentes em afirmar que tal diligência tinha 
tido sucesso parcial, e por que não dizer, provisório, devido estar "occupando a fazenda da Marambaia em espaço circunferencial de cerca de 20 legoas com elevadíssimos e escarpados montes cobertos de espessas mattas não se pode prestar aos bons resultados de uma diligência". Bem diferente do "parecer técnico" do IPHAN (de alguém que talvez nem tenha ido à ilha da Marambaia), que afirmou que a extensão do território da Marambaia "não favorece a existência de esconderijos seguros e a mobilidade tática de grupos aquilombados", sendo que "qualquer ajuntamento de quilombolas teria sido prontamente reprimido" e que "não teria muita dificuldade em prender os negros em situação de cerco natural, proporcionado pelas próprias condições geográficas" da ilha. Igualmente diferente do veredicto do parecer jurídico do procurador Leivas, de que "em nenhum momento existiram quilombos ou quilombolas na Marambaia, onde seriam presa fácil do comendador Breves" e "seria um absurdo que esses escravos procurassem fugir para o morro isolado, numa ilha, onde seriam facilmente apresados, cercados de mar por todos os lados" e "como seria possível constituir-se naquela área restrita, cercada de mar por todos os lados, sem recursos próprios, um quilombo?" ${ }^{60}$ Os relatos das autoridades que reprimiram o quilombo da Marambaia em 1870, documentos amarelados do século XIX depositados no Arquivo Nacional, no Fundo da Presidência da Província do Rio de Janeiro, ousam contradizer o procurador que garantia que não "poderia deixar passar impune essa verdadeira falsificação da história" na "tese da existência de um quilombo na Marambaia" que representava "um atentado grosseiro à História Pátria".

Mas a grande dificuldade de capturar os quilombolas da Marambaia não foi apenas a questão geográfica. Os argumentos que aparecem nos relatos da repressão de 1870 sugerem exatamente a construção de redes que conectavam escravos, senzalas, fazenda, fugitivos, quilombolas e expectativas de autonomia, liberdade e defesa de "direitos" na sociedade escravista, enfim novos formatos de quilombos históricos do

${ }^{60}$ Processo no $98.0007738-3$ - Ação de Reintegração de Posse ajuizada pela União Federal contra Sebastiana Camilla Henriqueta de Lima - Ministério Público Federal - 17 de dez. 2001, pp. 51-8. 
passado. Segundo o delegado de Mangaratiba, "uma outra circunstância se opõe a captura desses escravos e outros que se queirão [sic] occultar, a qual consiste em encontrarem auxílio nos parceiros da fazenda e seos parentes consentindo que elles pernoitem nas mesmas senzalas embrenhando-se durante o dia pelas mattas". Assim, a ação destes "aquilombados" consistia "na repugnância de serem remetidos para outras Fazendas que o Commendador Breves possue nos municípios de serra-cima, sendo de crer que elles se apresentarão logo que cesse essa intenção de seo Senhor".

Em 1996, o antropólogo Richard Price criticou a literatura antropológica no Brasil sobre as comunidades remanescentes de quilombo, especialmente em função do que considerava excessiva politização e pouco rigor acadêmico nas etnografias e estudos que procuravam demonstrar a existência delas em vários lugares. ${ }^{61}$ Consideramos que, talvez, Price tenha errado na mão, numa crítica que às vezes se aproximava de uma mistura de moralismo intelectual com argumento de autoridade acadêmica. O mais importante foi chamar atenção para as realidades conexas entre a luta por reconhecimento de territórios étnicos no Suriname, Colômbia e Brasil no século XX. As semelhanças do presente contêm diferenças no passado de quilombos, maroons, cumbes, mocambos e palenques. Provavelmente mais parecida com aquelas de áreas da Colômbia no pacífico ou com os grupos de fugitivos aparentemente isolados entre engenhos e conucos de Cuba, a história dos quilombos brasileiros, principalmente no século XIX, foi diferente da história daqueles coloniais, como Palmares, Quaritêre, Ambrósio ou seus semelhantes, como Saramakas no Suriname, São Basílio na Colômbia ou os quilombos jamaicanos. Em diversas áreas, na escravidão e no pós-Abolição, quilombos e "aquilombados" (termo sugestivo) podiam significar territórios movediços de complexas redes sociais, envolvendo práticas econômicas com interesses multifacetados. Assim, quilombos históricos continham e/ou estavam contidos nestes territórios - diversos "campos negros" - que se metamorfosearam em diferentes co-

${ }^{61}$ Richard Price, "Reinventando a história dos quilombos: rasuras e confabulações", Afro-Ásia, n. 23 (1999), pp. 239-65. 
munidades remanescentes quilombolas e comunidades negras rurais atuais. ${ }^{62}$ No Brasil, talvez mais do que em qualquer outra região das Américas, formas de aquilombamento, comunidades de senzalas e de camponeses livres (libertos e mestiços) estavam conectadas. Assim, assenzalados, comunidades formadas no pós-Abolição e aquilombados conquistaram margens de acesso, controle e utilização da terra, com formatações agrárias variadas. Não se misturaram, pois nunca estiveram separados, antes, compartilharam experiências. É possível propor uma explicação para a disseminação - não a nucleação - de pequenos e médios quilombos no Brasil, comparativamente a outras partes das Américas. No caso brasileiro, o espalhar de comunidades em áreas de fronteiras econômicas abertas e a perspectiva de atividades de roceiros que se articulavam com outros setores econômicos, transformando-as quase em invisíveis, aproximava-se das experiências dos palenques colombianos e de suas inúmeras comunidades negras rurais no pacífico, num processo de migrações identitárias visando ao acesso aos recursos naturais.

Estudos têm demonstrado a existência de vários tipos de aquilombamentos. Alguns se reproduziram ao longo do tempo, possuindo uma economia camponesa estável, produziam excedentes e mantinham trocas mercantis. Houve também aquilombamentos caracterizados como protestos reivindicatórios que procuravam se manter no interior das terras da própria fazenda, com extensas áreas. Também proliferaram pequenos grupos de quilombolas volantes, que praticavam assaltos a viajantes e a fazendas em busca de mantimentos. Embora com características diferentes de formação, organização e ação, esses tipos de aquilombamentos podiam coexistir numa mesma região em dado período e se integrarem. Enquanto os quilombos que formaram comunidades de roceiros possibilitaram, ao longo do tempo, a gestação de um campesinato negro - no qual as práticas econômicas próprias dos escravos, cada vez

${ }^{62}$ Para o caso da Ilha da Marambaia, no relatório técnico e científico sobre a comunidade, Arruti defende que: "O fim da escravidão foi bastante abrupto para os moradores da Marambaia. $\mathrm{O}$ seu isolamento do continente parece não lhes ter permitido o acesso à circulação de informações que existiu entre as senzalas e o que Gomes (1996) denominou de "campo negro". Ver: José Arruti (org.), Relatório técnico-científico sobre a comunidade remanescente de quilombo da Ilha da Marambaia, p.114. 
mais, podiam se vincular àquelas dos quilombolas -, os caracterizados como protesto reivindicatório podiam representar as respostas reelaboradas daqueles que permaneceram como cativos, transformando-se em legado no pós-Abolição. Já a migração constante dos pequenos grupos quilombolas produzia um cenário de campesinato itinerante, muito parecido com aqueles de famílias camponesas no alvorecer do século XX a procura de trabalho e acesso a terra.

As comunidades remanescentes quilombolas atuais são fruto desta diversidade e desdobramentos, e de outras tantas experiências das lutas agrárias do século XX, de formações históricas desde terras herdadas de quilombolas/escravos fugidos e seus descendentes da escravidão até de doações de senhores ou ordens religiosas a ex-escravos; terras compradas por libertos e herdadas pelos seus descendentes; terras conseguidas do Estado em troca de participação em guerras ou ainda de inúmeras migrações de libertos e suas famílias no período imediatamente pós-Abolição.

$\mathrm{Na}$ formação de um campesinato negro sempre houve uma articulação entre os quilombos, a economia local e os setores sociais envolventes. Em função do não-isolamento e ao mesmo tempo da estratégia de migração, muitos quilombos sequer foram identificados e reprimidos por fazendeiros e autoridades durante a escravidão. Outros, na mesma ocasião, acabaram sendo reconhecidos como vilas de camponeses negros que efetuavam trocas mercantis, interagindo com a economia local envolvente. Destaca-se ainda formação de "comunidades de senzalas", comunidades negras rurais (formadas ainda na escravidão e com desdobramento no pós-Abolição) com cativos e libertos de um mesmo proprietário ou de um conjunto de proprietários, organizadas por grupos de trabalho, famílias, compadrio e base religiosa que hoje representam as centenas de "terras de preto" ou "terra de santo" em várias fronteiras agrárias. Além disso, a questão da identidade étnica não foi tão somente uma construção do presente, mas estava colocada nas formas de classificação e paisagens rurais no século XIX e antes. ${ }^{63}$

${ }^{63}$ Ver: B. J. Barickman, "As cores do escravismo: escravistas 'pretos', 'pardos' e 'cabras' no Recôncavo baiano, 1835". População e Família, v. 2, n. 2 (1999), pp. 7-62; Costa, ArraíaMiúda; e Klein, "Os homens livres de cor na sociedade escravista brasileira, pp. 3-27. 
A questão das fontes (ausência muitas vezes) não pode constituir obstáculos. A memória do campesinato negro e a organização de milhares de micro-sociedades são reveladoras destas simbioses e conexões das várias experiências pretéritas dos quilombolas entrelaçadas com migrações, doações e práticas costumeiras de acesso a terra no pósAbolição. Mesmo para os quilombos do passado, os estudos tem se baseado na documentação de natureza policial, em geral, ofícios de delegados, juízes de paz, presidentes de província e ministro da justiça, relativa à repressão realizada (ou necessidade dela) com expedições. Para Minas Gerais e Mato Grosso, no período colonial, e para o Maranhão, no século XIX, temos substantivos relatórios de expedições punitivas, nos quais aparecem registros da vida comunitária e mesmo da cultura material dos quilombos. ${ }^{64}$ Mas são casos raros, pois, na maioria das vezes, o historiador dos quilombos do passado tem em mãos pequenos relatórios e cartas de autoridades policiais e alguns poucos depoimentos de capturados. Mesmo processos-crimes envolvendo quilombolas são raros, apenas aparecem nestes quando envolvidos em crimes de revoltas e assassinatos. Para o século XIX, um bom recurso de investigação são os periódicos que noticiavam desde denúncias, reclamações dos leitores em cartas com pseudônimos até o noticiário policial sobre a repressão. Assim como a cartografia colonial e a toponímia, a legislação antimocambos continua pouco explorada. Era comum a existência de extensa legislação - no âmbito das câmaras locais - nomeando capitães do mato, tomadias, tipologias e punições para quilombolas e acoitadores, embora esta, por vezes, antecedesse por décadas à efetiva localização e repressão direta a quilombos mais estáveis. ${ }^{65}$ Para além de uma definição "frigorificada" como insistem alguns, a ampla e diversificada legislação sobre quilombolas pode ajudar a pensar não numa definição cristalizada, mas, pelo contrário, as diversas experiências dos

${ }^{64}$ Ver: Mathias Rohrig Assunção, "Quilombos Maranhenses”; Laura de Mello e Sousa, "Violência e práticas culturais no cotidiano de uma expedição contra quilombolas - Minas Gerais, 1769"; e Luíza Rios Ricci Volpato, "Quilombos em Mato Grosso - Resistência negra em área de fronteira", in Reis e Gomes (orgs.), Liberdade por um fio, respectivamente, pp. 433-66, $193-212$ e $222-26$

65 Silvia Hunold Lara, "Do singular ao plural: Palmares, capitães-do-mato e o governo dos escravos", in Reis e Gomes, Liberdade por um fio, pp. 81-109. 
quilombos (inicialmente, no século XVII, denominados mais genericamente de mocambos) e apropriações por parte das autoridades coloniais e imperiais. Informações sobre o número de fugitivos, a distância para a sua captura, a existência ou não de casas e pilões são reveladoras desta diversidade do passado que certamente produziu desdobramento no presente. Também a legislação do Conselho Ultramarino de 1740, que definia o quilombo, deve ser matizada tanto na crítica ao seu uso como na rejeição, uma vez que as notícias dos quilombos datavam na América portuguesa pelo menos desde 1580. Sem falar da combinação original, das conexões entre setores livres e escravos, incluindo os escravos fugidos. Talvez esta seja a explicação do silêncio da legislação sobre os quilombos no século XIX só repetindo a legislação colonial e o completo desaparecimento de definições no pós-Abolição do século XX. Representaram, no caso brasileiro, milhares de comunidades negras que abundavam e misturavam quilombolas, grupos de fugitivos, vilas de libertos e trabalhadores rurais diversos e agregados em várias dimensões agrárias.

\section{ANEXOS}

Arquivo Nacional - Série Justiça, Ofícios de Presidente de Província, Maço $478{ }^{66}$

Cópia - Ilustríssimo e Excelentíssimo Senhor. Em cumprimento a portaria reservada de 6 do corrente, tenho o dever de levar ao conhecimento de Vossa Excelência o resultado da diligência a que procedi na fazenda da Marambaia de propriedade do comendador Joaquim José de Souza Breves, procedendo em tudo de perfeito acordo com as instruções contidas no referido reservado como depreenderá Vossa Excelência do auto de apreensão e busca que por cópia junto a este. No dia 8 à meia noite em ato contínuo ao do recebimento dos ofícios e da apresentação da força segui acompanhado dela para o lugar indicado e aí chegando, ás 4 horas da manha do dia seguinte, ordenei imediatamente que fossem cercados todas as senzalas da fazenda para onde conver-

${ }^{66}$ A ortografia dos documentos foi atualizada 
giam todas as suspeitas de lá se acharem os fugitivos. De feito, aí se acharam cinco deles e, não obstante serem tomadas todas as precauções, só se pode conseguir a captura de um, enquanto os outros quatro não atendendo as intimações feitas, e usando de duas armas que consigo traziam dispararam sobre a escolta, conseguindo evadirem-se enquanto que esta, procurando intimidá-los, usou do artifício de dar dois ou três tiros ao ar, não resultando de tudo isso ferimento algum. $\mathrm{Na}$ suposição de conseguir mais algum resultado, determinei excursões pelas vastas matas da fazenda, porém baldados foram os esforços empregados, não se encontrando também nessas excursões quilombo algum, nem constando havê-los, a exceção dos vestígios de um que antecipadamente já tinha sido destruído pelos próprios fugitivos. Depois de concluída a diligência apresentou-se-me um dos fugitivos de nome Felisberto, o qual, juntamente com o que tinha sido encontrado na senzala, foi entregue ao mesmo comendador Joaquim Breves por se reconhecer ser de sua propriedade. Pelas minuciosas informações que coIhi e exame a que procedi, devo informar a Vossa Excelência que qualquer que sejam as precauções tomadas em uma diligência naqueles lugares não se poderia obter resultado algum favorável, por isso que ocupando a fazenda da Marambaia em espaço circunferencial de cerca de 20 léguas com elevadíssimos e escarpados montes cobertos de espessas matas não se pode prestar aos bons resultados de uma diligência. Uma outra circunstância se opõe a captura desses escravos e outros que se queiram ocultar, a qual consiste em encontrarem auxílio nos parceiros da fazenda e seus parentes consentindo que eles pernoitem nas mesmas senzalas embrenhando-se durante o dia pelas matas. Contudo, é forçoso confessar a Vossa Excelência que se por um lado não se obteve resultado satisfatório com essa diligência, por outro me parece que o ato de Vossa Excelência será salutar à moralidade dessa e outras escravaturas do município. Informando-me acerca dos motivos que deram lugar a fuga desses escravos, que hoje são em número de dez, consiste ela na repugnância de serem remetidos para outras fazendas que o comendador Breves possui nos municípios de serra acima, sendo de crer que eles se apresentarão logo que cesse essa intenção de seu senhor. Eis o que me cumpre levar ao conhecimento de Vossa Excelência, devendo acrescentar que o meu pesar por não haver 
conseguido o completo resultado dessa diligência está na razão dos esforços nela empregados para a boa realização. Concluindo devo manifestar a Vossa Excelência a minha satisfação pelo modo por que se portaram neste serviço o senhor major Antônio Luiz Rodrigues e mais praças sob seu comando, os quais se tornavam dignos de todo o elogio. Deus guarde a Vossa Excelência. Delegacia de Policia do Termo de Mangaratiba, em 12 de setembro de 1870. Ilustríssimo e Excelentíssimo Senhor Doutor Antônio Carneiro de Campos. Mui digno chefe de Polícia desta província. O delegado de Polícia João Dias Cardoso. Conforme Antônio Luiz Pereira da Cunha, secretário.

Cópia. Reservado. Secretaria de Polícia da Província do Rio de Janeiro. Niterói, 17 de setembro de 1870. Ilustríssimo e Excelentíssimo Senhor. Transmito a Vossa Excelência a inclusa cópia do ofício que me dirigiu o delegado de Polícia do Termo de Mangaratiba dando conta do resultado da diligência de que me incumbi para realizar a prisão de alguns escravos da fazenda da Marambaia pertencente ao comendador Joaquim José de Souza Breves, os quais tendo desobedecido a seu senhor que procurava removê-los para uma outra fazenda haviam se aquilombado e procuravam seduzir os demais que se conservaram obedientes. A diligência não foi tão completa como se desejava pelos motivos muito valiosos que dá o delegado, mas a energia e a prontidão na remessa da força produziram bons resultados e o delegado acredita que os escravos irão se apresentando como já fizera um deles, havendo a força apenas capturado um outro. Deus Guarde a Vossa Excelência. Ilustríssimo e Excelentíssimo Doutor José Maria Corrêa de Sá e Benevides, presidente desta província $=O$ chefe de Polícia Antônio Carneiro de Campos $=$.

$1^{a}$ Seção Palácio do Governo da Província do Rio de Janeiro Niterói, 19 de setembro de 1870

Ilustríssimo e Excelentíssimo Senhor

Tendo o chefe da Polícia desta província, em ofício de 29 de agosto último, comunicado a esta presidência acharem-se aquilombados na fazenda da Marambaia, de propriedade do comendador Joaquim José 
de Souza Breves, diversos escravos deste que por sua ordem tinham sido removidos para uma outra fazenda, e procuravam seduzir os demais escravos, resolvi fazer seguir para aquela fazenda uma força de trinta praças do Corpo Policial sob comando de um oficial a fim, de acordo com o delegado do termo de Mangaratiba, não só proceder a prisão daqueles escravos que haviam desobedecido ao referido comendador Breves, como também para restabelecer a ordem na dita fazenda. O resultado da diligência consta do ofício do dr. chefe de Polícia, que tenho a honra de enviar a Vossa Senhoria.

Deus guarde a Vossa Excelência. Ilustríssimo e Excelentíssimo conselheiro barão de Muritiba, ministro e secretário de Estado interino dos Negócios da Justiça.

$3^{a}$ Seção Despacho de Sua Excelência o Senhor Ministro Rio de Janeiro

Denúncia de existir na Marambaia um quilombo de escravos Em ofício de 19 de setembro corrente participa o presidente da província do Rio de Janeiro ter lhe comunicado o chefe de Polícia que na fazenda da Marambaia, propriedade do comendador Joaquim José de Souza Breves, achavam-se aquilombados diversos escravos, que tinham sido removidos para outra fazenda por ordem de seu senhor, procurando esses seduzir os demais escravos.

O chefe de Polícia, em ofício de 17 do corrente mês, remeteu à Presidência a cópia da informação que lhe foi dada a este respeito pelo delegado de Polícia do termo de Mangaratiba, a quem tinha encarregado de uma diligência com o fim de realizar a prisão desses escravos. $O$ dito delegado tendo se dirigido à fazenda da Marambaia com força de 30 praças do Corpo Policial que foi posta à sua disposição, mandou cercar as senzalas dessa fazenda, e aí foram encontrados cinco fugitivos. Só se pôde conseguir a captura de um deles enquanto que outros quatro, não atendendo às intimações que lhes foram feitas e usando de armas que consigo traziam, dispararam sobre a escolta e conseguiram evadirem-se. A forca policial procurou, para intimidá-los, usar do artifício de dar dois ou três tiros ao ar. 
Nenhum ferimento houve.

Foram depois feitas algumas excursões pelas matas, tornando-se baldados todos os esforços em consequência de ocupar aquela fazenda um espaço de vinte léguas de circuito, com elevados e escarpados montes, cobertos de espessas matas. Além disto, estes escravos fugitivos encontram fácil proteção em seus parceiros, que lhes consentem pernoitar nas mesmas senzalas; e durante o dia embrenham-se pelas matas.

Não se encontrou vestígio algum de quilombo. O motivo que deu lugar a fuga desses escravos em número de dez, consiste na repugnância que eles têm de serem removidos para outras fazendas que possui o comendador Breves nos municípios de serra acima.

Informa o delegado que o major Antônio Luiz Rodrigues e mais praças tornaram-se nessa diligência dignos de elogio.

[Creio que se deva acusar o recebimento do ofício recomendando ao presidente a continuação de providência no sentido e capturar os escravos que resistiram à força policial. 30 de setembro de 1870]

$1^{a}$ Seção Palácio do Governo da Província do Rio de Janeiro

Niterói, 30 de setembro de 1870

Ilustríssimo e Excelentíssimo Senhor

Em referência ao meu ofício de 19 deste mês, cabe-me o dever de participar a Vossa Excelência que no dia 26 foi assassinado na Fazenda da Marambaia pertencente ao comendador Joaquim José de Sousa Breves, o administrador da mesma fazenda Francisco Costa e gravemente ferido o ajudante deste, Sabino Barboza, por escravos que estavam foragidos, achando-se preso o crioulo Isidoro, que é indigitado como o perpetrador de tais crimes.

A autoridade local procedeu aos respectivos corpos de delito e continuo nas demais averiguações no sentido de descobrir se existem outros indivíduos envolvidos em semelhante atentado. Do resultado do respectivo processo e dos demais esclarecimentos que colher à respeito. Darei parte a Vossa Excelência oportunamente.

Deus guarde a Vossa Excelência 
Ilustríssimo e Excelentíssimo Senhor conselheiro barão das Três Barras, ministro e secretário de Estado dos Negócios da Justiça.

$1^{a}$ Seção Palácio do Governo da Província do Rio de Janeiro

Niterói, $1^{\circ}$ de outubro de 1870

Ilustríssimo e Excelentíssimo Senhor

Em referência ao meu ofício de 30 de setembro último, cabe-me o dever de participar a Vossa Excelência que em ofício de 5 do corrente mês comunicou-me o chefe de Polícia desta província haver o subdelegado da freguesia de Itacurussá em Mangaratiba procedido o corpo de delito no cadáver do administrador da fazenda da Marambaia, Francisco Costa, e nos ferimentos do ajudante deste, Silvino Barboza, prosseguindo o respectivo delegado nas diligências precisas para a captura de mais oito escravos da mesma fazenda que também se acham envolvidos no crime de que foram vítimas aqueles indivíduos.

Deus guarde a Vossa Senhoria.

Ilustríssimo e Excelentíssimo senhor conselheiro barão das Três Barras, ministro e secretário de Estado dos Negócios da Justiça.

Texto apresentado e aceito em 14 de julho de 2012 


\title{
Resumo
}

Neste artigo discutimos as conexões entre história, direitos humanos e cidadania a partir da temática das comunidades remanescentes de quilombos e as suas lutas para garantir a posse e a ocupação dos seus territórios com base nos dispositivos da Constituição de 1988 e na regulamentação complementar do século XXI. Desde a década de 1980 os remanescentes quilombolas da Marambaia, área de antigas fazendas e quilombos no século XIX localizada no sul fluminense (RJ), resistem às ações da Marinha, do governo federal e da Justiça para se manterem na região e garantirem autonomia sobre os seus territórios e culturas. Analisamos aqui as várias etapas, os agentes envolvidos (advogados, juristas, antropólogos, arqueólogos, organizações não-governamentais, Ministério Público e órgão dos governos federal e estadual) e os argumentos em torno da memória e dos usos e sentidos da história e da legislação envolvente sobre quilombolas e seus direitos. Apresentamos ainda a transcrição e análises de documentos inéditos sobre a ocupação quilombola na região em 1870.

Palavras-chave: comunidades negras rurais remanescentes de quilombos Marambaia (RJ) - memória e cidadania

\begin{abstract}
This article discusses the connections between history, human rights and citizenship, through the lens of the struggles by communities founded as quilombos to legalize their land occupancy based on the provisions of the 1988 Constitution and on complementary regulations passed in the $21^{\text {st }}$ century. Since the 1980s, the inhabitants of the Marambaia quilombo, an area located in the southern Fluminense region of Rio de Janeiro, which in the 1800s consisted of plantations and quilombos, have fought to maintain their lands and to ensure their cultural and territorial autonomy in the face of pressure from the Brazilian Navy, the Federal Government and the court system. The paper discusses the various stages of this struggle and the diverse actors who have entered the scene (lawyers, judges, anthropologists, archeologists, NGOs, Brazil's Public Ministry as well as federal and state governmental agencies) and the discourse on memory the meanings and uses of history and of the legislation on quilombo residents and their rights. The article also includes transcriptions and analyses of newly uncovered historical documents from 1870 referring to the existence of quilombos in the region.
\end{abstract}

Keywords: rural black communities - quilombos - Marambaia (Rio de Janeiro) - memory and citizenship 